This is a postprint version of the following published document:

Martin, R., Muûls, M., Wagner, U. J. (2016). The impact of the European Union Emissions Trading Scheme on regulated firms: what is the evidence after ten years?. Review of Environmental Economics and Policy, v. 10, $\mathrm{n}$. 1, pp. 129 148. Available in https://doi.org/10.1093/reep/rev016.

(c) Oxford University Press 


\title{
The Impact of the European Union Emissions Trading Scheme on Regulated Firms: What Is the Evidence after Ten Years?
}

\author{
Ralf Martin*, Mirabelle Muûls ${ }^{\dagger}$, and Ulrich J. Wagner*
}

\section{Introduction}

Since its inception in 2005, the European Union (EU) Emissions Trading Scheme (ETS) has changed the framework for doing business in Europe's power sector and energy-intensive industries. The policy limits the annual aggregate emissions of carbon dioxide $\left(\mathrm{CO}_{2}\right)$ by allocating a certain amount of pollution permits, called European Union Allowances (EUAs), to each participating emitter. At the end of each year, emitters must surrender an EUA for each ton of $\mathrm{CO}_{2}$ emitted, but they are free to buy additional EUAs or sell excess EUAs on an international permit market. The primary goal of this cap-and-trade policy is to achieve a given reduction target for aggregate $\mathrm{CO}_{2}$ emissions at minimal cost. A longer-term objective is to stimulate innovation that will help with the transition to a low-carbon economy.

A thorough understanding of how regulated firms have responded to the EU ETS is crucial for improving not only this specific policy but also carbon trading schemes in other parts of the world (e.g., the Regional Greenhouse Gas Initiative in the United States). The first 10 years of carbon trading in Europe have generated large amounts of data suitable for a sweeping ex post

\footnotetext{
* Imperial College Business School, South Kensington Campus, London SW7 2AZ, United Kingdom, Grantham Institute on Climate Change, and Centre for Economic Performance (CEP); e mail: r.martin@imperial.ac.uk.

$\dagger$ Grantham Institute and Imperial College Business School, Imperial College London, South Kensington Campus, London SW7 2AZ, and Research Associate, CEP; e mail: m.muuls@imperial.ac.uk.

$\$$ Department of Economics, University of Mannheim, L7, 3 5, 68131 Mannheim, Germany; e mail: wagner@vwl.uni mannheim.de.
}

This article is based on a report commissioned by the UK Department of Energy and Climate Change (DECC) (Martin, Muûls, and Wagner 2012). We thank Aproop Bhave, Raphael Calel, Denny Ellerman, Duncan Grey, Beat Hintermann, Claudio Marcantonini, Sonja Peterson, Wilfried Rickels, Kate Viner, and Aleksander Zaklan for providing helpful comments on an earlier draft. We are indebted to our coauthors Jonathan Colmer, Antoine Dechezleprêtre, Sebastian Petrick, Laure de Preux, and Katrin Rehdanz for their help and insights in countless conversations about the EU ETS. We thank Suzy Leonard and Charlie Kolstad at REEP for helpful comments and suggestions. We gratefully acknowledge financial support from DECC, the ESRC (grant ES/ J006742/1), the British Academy (Martin), the Leverhulme Trust (Muûls), and the Spanish Ministries of Science and Innovation, and Economics and Competitiveness, reference numbers SEJ2007 62908, ECO2012 31358 and RYC 201312492 (Wagner). 
analysis of the effectiveness and success of the EU ETS. However, no single study has been able to accomplish this formidable task. Thus, the purpose of this article, which is part of a symposium on the EU ETS, ${ }^{1}$ is to summarize and evaluate the existing ex post literature on the EU ETS, focusing in particular on the impact of the EU ETS on the $\mathrm{CO}_{2}$ emissions, economic performance and competitiveness, and innovation of regulated firms in the industrial and power sectors.

An ideal evaluation of the EU ETS would combine a representative firm- or plant-level data set of sufficient detail with a study design that attributes to the EU ETS only those observed behavioral changes it has actually caused. It is difficult to solve this identification problem because there are so many factors that might simultaneously affect firm behavior, thus confounding the impact estimate. The state-of-the-art solution would be to conduct a randomized control trial or field experiment (e.g., Greenstone and Gayer 2009). As in other real-world settings, however, randomizing participation in the EU ETS is neither desirable nor politically feasible. Thus, evaluations of the EU ETS have generally relied on more traditional econometric techniques ${ }^{2}$ to estimate the average effect of the EU ETS on treated (i.e., regulated) firms, which implicitly assume that the EU ETS has no effect on untreated (i.e., unregulated) firms. This is a strong assumption because if the EU ETS were to cause output prices in the electricity sector to rise, those price increases would be likely to affect the industrial sector as a whole, thus blurring the distinction between treated and untreated firms. Although the direct impact of the EU ETS can be estimated by comparing participating firms with suitable controls among nonparticipants, it is very challenging to separately identify the specific impact of higher electricity prices. Although the studies we review in this article all focus on estimating the direct impact of the EU ETS on power plants and industrial plants, it is important to recognize that the estimated impact of the EU ETS on industrial polluters also includes its indirect impact via higher electricity prices.

Our choice of studies to include in our review was based on a systematic search of the scholarly literature and the application of well-defined criteria. ${ }^{3}$ Although we considered both published and unpublished research, all of the papers included in our review are original research studies based on actual data collected ex post (i.e., during the treatment period). This rules out review papers, policy briefs, and analytical papers based on simulations.

The remainder of this article is organized as follows. In individual sections, we review the research findings concerning the impacts of the EU ETS on emissions abatement, economic performance and competitiveness, and innovation, respectively. Within each section, we place more weight on studies that seek to establish causality. The final section summarizes the main findings and suggests priorities for future research on the EU ETS

\section{Impact of the EU ETS on Emissions Abatement}

Given the objectives of the EU ETS, measuring the policy's impact on emissions is crucial. By definition, a cap-and-trade system like the EU ETS will produce emission reductions as long as

\footnotetext{
${ }^{1}$ The other articles in the symposium are Ellerman, Marantonini, and Zaklan (2016), which introduces the symposium and provides a broad overview of the EU ETS, and Hintermann, Peterson, and Rickels (2016), which reviews the literature on price and market behavior during phase II of the EU ETS.

${ }^{2}$ These approaches include matching, regression discontinuity design, and instrumental variable (IV) estimation.

${ }^{3}$ For more details on this process, see the online supplementary materials.
} 


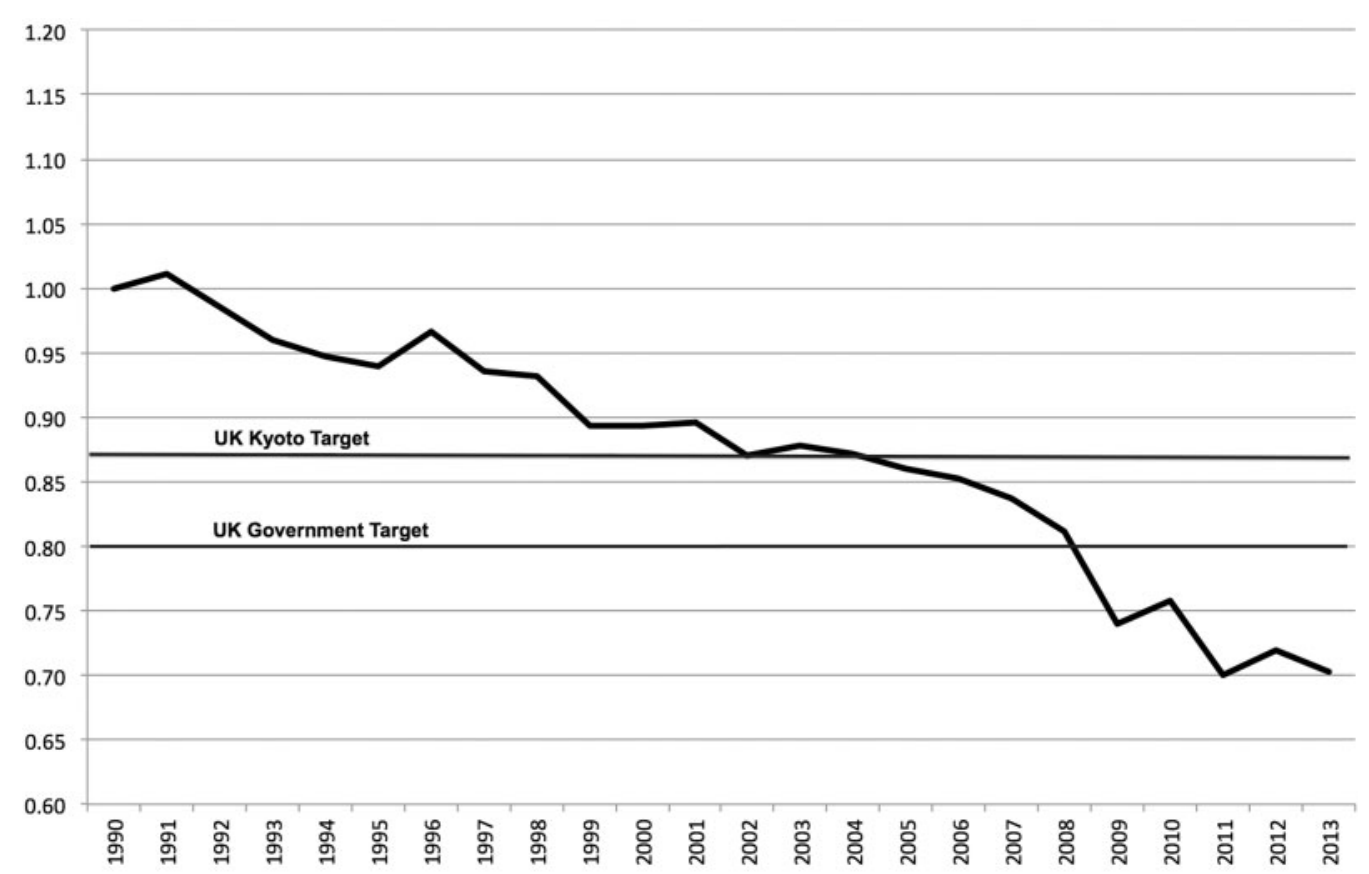

Figure I UK emissions 1990-2013

Notes: 1990 is taken as base year. The Kyoto target is in terms of total greenhouse gas emissions. The government target is in terms of $\mathrm{CO}_{2}$.

Source: DECC (2013).

the cap is set tightly enough and regulated emitters are not in gross violation of the scheme. However, this does not mean that an observed decline in emissions can automatically be attributed to the ETS. In many industries and countries, emissions have been declining for some time. For example, in the United Kingdom, emissions decreased by 29.8 percent between 1990 and 2013 (see figure 1). Moreover, macroeconomic fluctuations such as the recent recession affect emissions, sometimes drastically. Thus, one should consider an emissions trading scheme to be effective only if it leads to emissions that are lower than would have been the case without the policy.

Researchers seeking to estimate the impact of the EU ETS on emissions in the power or industrial sector have encountered two major challenges. First, for installations included in the EU ETS, data on emissions prior to 2005 were not readily available. Second, a suitable measure of counterfactual emissions is needed. Several methods to measure pre-2005 emissions and estimate this counterfactual (i.e., business-as-usual [BAU] emissions) have been proposed in the literature. We review three major strands of this literature: estimates based on aggregate emissions, estimates based on emission data at the firm or plant level, and qualitative studies based on interviews and case studies.

\section{Estimates Based on Aggregate Emissions}

Emissions aggregated at the sector level have been used to estimate the impact of the different phases of the EU ETS on both industrial emissions and the electricity sector. 
Table I Estimates of phase I abatement based on aggregate emissions data

\begin{tabular}{|c|c|c|c|c|c|}
\hline Authors & $\begin{array}{l}\text { Estimated } \\
\text { abatement }\end{array}$ & Country & $\begin{array}{l}\text { Time } \\
\text { period }\end{array}$ & Sector & Data source \\
\hline Ellerman and Buchner (2008) & $\begin{array}{l}50 \text { to } 100 \mathrm{Mt} \\
\text { per year } \\
\text { ( } 2.4 \% \text { to } 4.7 \% \text { ) }\end{array}$ & EU & 20052006 & All & NAP \\
\hline $\begin{array}{l}\text { Ellerman, Convery, } \\
\text { and de Perthuis (2010) }\end{array}$ & $\begin{array}{l}70 \text { Mt per year } \\
(3.3 \%)\end{array}$ & EU & 20052007 & All & CRF (UNFCCC) \\
\hline Anderson and Di Maria $(20 \mathrm{II})$ & $\begin{array}{l}58 \text { Mt per year } \\
(2.8 \%)\end{array}$ & EU & 20052007 & All & Eurostat \\
\hline Ellerman and Feilhauer (2008) & $\begin{array}{l}28.5 \mathrm{Mt} \text { per year } \\
(5.7 \%)\end{array}$ & Germany & 20052007 & All & CRF (UNFCCC) \\
\hline Ellerman and Feilhauer (2008) & $\begin{array}{l}\text { II.7 Mt per year } \\
(6.3 \%)\end{array}$ & Germany & 20052007 & Industry & CRF (UNFCCC) \\
\hline
\end{tabular}

Notes: NAP are National Allocation Plans (DEHSt 2005). CRF (UNFCCC) are National Inventory Reports submitted to the United Nations Framework Convention on Climate Change in the Common Reporting Format (BBD 2008). Eurostat holds an inventory of greenhouse gas emissions (EEA 2007).

\section{Phase I emissions}

Three sources of data have been used to estimate pre-2005 emissions in order to construct the counterfactual BAU for the 2005-2007 (i.e., phase I) period. The estimates and their data sources are summarized in table 1. First, focusing on the first two years of phase I (20052006), Ellerman and Buchner $(2007,2008)$ extrapolate pre-2005 emissions data from National Allocation Plans (NAPs) ${ }^{4}$ by taking into account gross domestic product (GDP) growth and the decreasing trend in the carbon intensity of production (i.e., emissions/GDP). However, there are two problems with the NAP data. The first problem is that the data were collected under time pressure, with minimal verification by authorities. Thus, installations had an incentive to inflate emissions if they expected that doing so would give them a more generous allocation of EUAs. The second problem is that the data are not perfectly comparable across countries because different calculation methods and base years were used for different countries. Ellerman and Buchner (2008) estimate that $\mathrm{CO}_{2}$ emissions were reduced by between 100 and 200 million tons across all EU ETS sectors and countries in the 2005-2006 period, which corresponds to a total abatement rate of between 2.4 percent and 4.7 percent.

Second, Herold (2007) uses adjusted United Nations Framework Convention on Climate Change (UNFCCC) common reporting format (CRF) data as a proxy for EU ETS sectors' historical emissions. To improve on the NAP data, Ellerman, Convery, and de Perthuis (2010) also use CRF data and estimate carbon emission reductions of close to 210 million tons (or 3 percent) over all 3 years of phase I (see figure 2).

The third source of data is Eurostat. ${ }^{5}$ Anderson and Di Maria (2011) match emissions data from Eurostat for a subset of industries to the corresponding EU ETS sectors. They also improve the calculation of the BAU emissions scenario for each country by including industrial

\footnotetext{
${ }^{4}$ In phases I and II of the EU ETS, each member state drew up an NAP that fixed the national cap and determined the sectoral permit allocation.

${ }^{5}$ Eurostat is the European Union's statistical office. It collects data on greenhouse gas emissions by industry. See http://ec.europa.eu/eurostat/statistics explained/index.php/Greenhouse gas emissions by industries and households.
} 


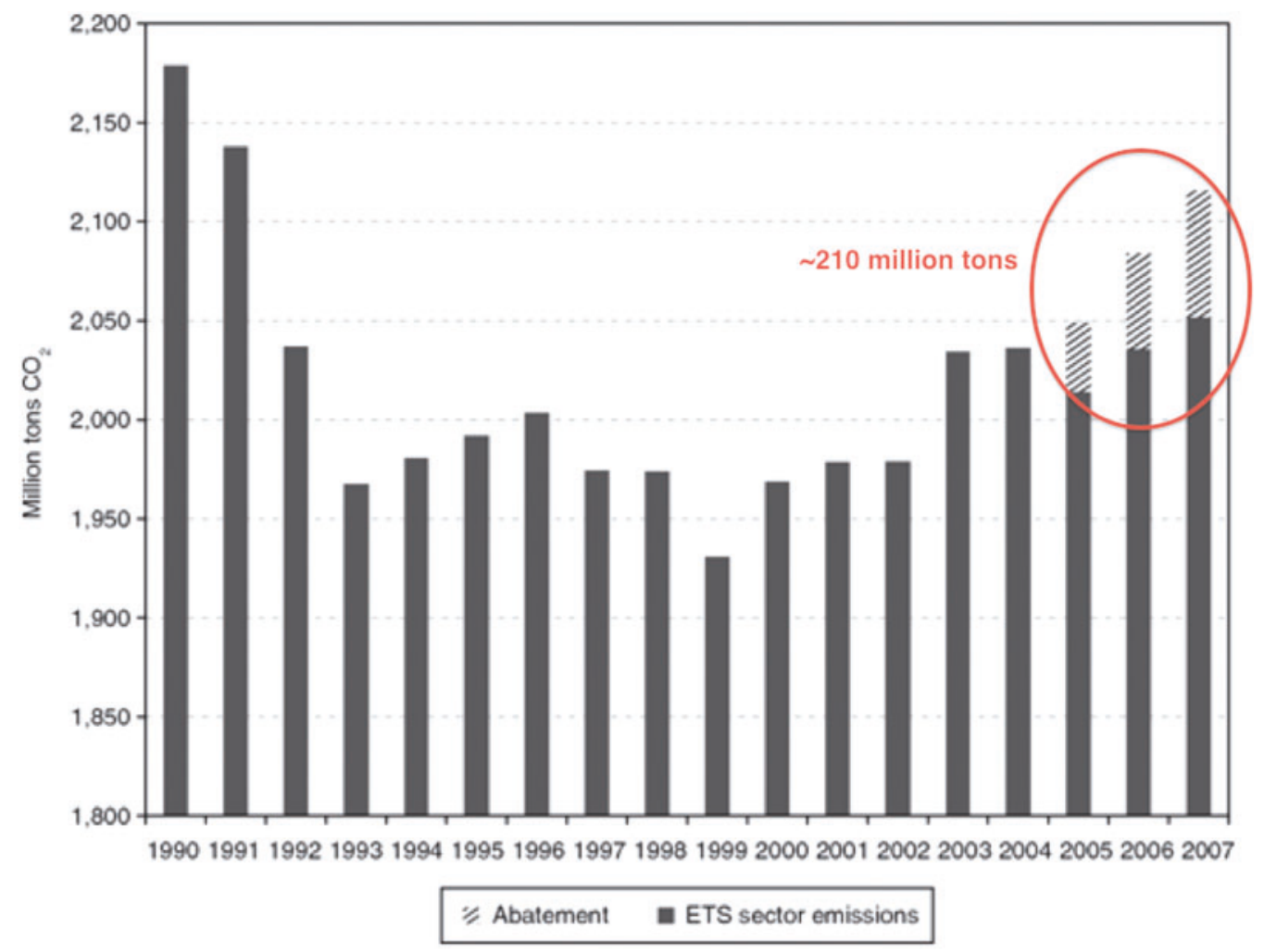

Figure 2 Emissions and abatement in the EU

Source: Ellerman, Convery, and de Perthuis (2010). Figure 6.2, p. 165 based on CITL, World Economic Outlook database, and EEA greenhouse gas data.

production data, energy production, and energy prices, as well as information on temperature and precipitation. They estimate overall abatement during phase I at 2.8 percent.

Both Ellerman, Convery, and de Perthuis (2010) and Anderson and DiMaria (2011) estimate emission reductions over phase I across all sectors and countries at close to 3 percent and show that abatement varies greatly across countries. Most of the abatement in phase I occurred in the EU15 countries ${ }^{6}$ rather than in Eastern European countries. Ellerman and Feilhauer (2008) focus on Germany and find that, during phase I, abatement per year due to the EU ETS was close to 5 percent for all EU ETS sectors. The authors divide this overall effect into a 6.3 percent reduction in the industrial sectors and a 4.1 percent reduction in power generation.

\section{Phase II emissions}

Egenhofer et al. (2011) extend the analysis by Ellerman, Convery, and de Perthuis (2010) to estimate $\mathrm{CO}_{2}$ abatement during the first 2 years of phase II (2008-2009). ${ }^{7}$ The overall emission intensity improvements attributed to the EU ETS are estimated at 3.35 percent on average, or 0.45 percent specifically for the industrial sectors. In an even more aggregate analysis, Cooper (2010) examines the 2 percent decline in industrial production between 2007 and 2008 due to the recession and the 3 percent decline in total emissions over the same period and concludes

${ }^{6}$ Austria, Belgium, Denmark, Finland, France, Germany, Greece, Ireland, Italy, Luxembourg, the Netherlands, Portugal, Spain, Sweden, and the United Kingdom

${ }^{7}$ Phase II was from 2008 to 2012, and phase III runs from 2013 to 2020. 
that the EU ETS did not reduce emissions much in 2008. Kettner, Kletzan-Slamanig, and Köppl (2011) arrive at a similar conclusion for the 2005-2009 period, finding that aggregate energy intensity declined, mainly in the pulp and paper industry.

\section{Electricity sector emissions}

The electricity sector plays a crucial role in abatement under the EU ETS. Trotignon and Delbosc (2008) and Ellerman, Convery, and de Perthuis (2010) find that emissions by this sector exceeded its EUA allocation in 2005 and 2006, despite receiving more than 40 percent of the total annual EUA allocation. Hintermann, Peterson, and Rickels (2016) explain that electricity generators can switch fuels to abate emissions in the short run, which often does not require any additional investment. However, because of the scarcity of disaggregated data and the complexity of the EU electricity market, most research on the impact of the EU ETS on electricity sector emissions has been forced to rely on simulation models rather than ex post analysis (Delarue, Voorspools, and D'haeseleer 2008; Delarue, Ellerman, and D'haeseleer 2010). Thus, although existing evidence does not suggest a strong effect of the EU ETS on the electricity sector's emissions, more refined data and research are needed to be able to draw more robust conclusions.

\section{Estimates Based on Firm-Level Emissions}

A key advantage of country-level studies is that they produce an estimate of the economy-wide abatement impact that is comprehensive and easy to communicate to academics and policymakers alike. The drawback of this approach is that it does not indicate causality and that it may be susceptible to aggregation error. More specifically, because participation in the EU ETS is determined by capacity thresholds for combustion installations and for narrowly defined industrial processes, an analysis based on sector-level data will inevitably count some emissions from untreated (i.e., nonparticipating) firms as EU ETS emissions and vice versa. The use of microdata at the firm or plant level solves this problem. Moreover, microdata facilitate the calculation of more credible estimates of the causal impact of the EU ETS by enabling the researcher to compare outcomes prior to and after the policy change at both treated and untreated plants. ${ }^{8}$ Unfortunately, emissions data for untreated plants and pretreatment years are not available from the EU's emissions trading registry-the European Union Transaction Log (EUTL; known as CITL prior to phase III), which is the main source of data on emissions and allocations of permits to participants in the EU ETS.

\section{Microdata from administrative sources}

Two recent studies use microdata from administrative sources, which, in addition to being highly representative and reliable, allow for very precise calculations of $\mathrm{CO}_{2}$ emissions based on detailed energy-use information for a wide range of fuel types. Petrick and Wagner (2014) link participating firms in the EUTL to a panel comprised of all German manufacturing plants with more than twenty employees (see Petrick, Rehdanz, and Wagner 2011). They find that the EU ETS had a significant impact on emissions only between 2008 and 2010, causing participating firms to reduce their emissions by 26 percent relative to nonparticipating firms. They also find

${ }^{8}$ Such a comparison, known as "differences in differences" (DD), purges the treatment estimate of confound ing factors such as the overall decline in aggregate energy use shown in figure 1. 
that this was driven by reduced oil and natural gas use, whereas output and electricity use remained unaffected by the EU ETS. Drawing on additional data from manager surveys, the authors suggest that the main source of abatement was the more efficient use of process heat.

Similarly, Wagner et al. (2013) link French manufacturing installations in the EUTL to microdata on energy use and find a statistically significant reduction in $\mathrm{CO}_{2}$ emissions during phase II of close to 16 percent. $^{9}$

\section{Data on the transition from phase I to phase II}

The studies for France and Germany use microdata on emissions prior to implementation of the EU ETS. In contrast, Abrell, Ndoye, and Zachmann (2011) use EUTL firm-level data to estimate reductions in $\mathrm{CO}_{2}$ emissions induced by the transition from phase I to phase II. ${ }^{10}$ Controlling for turnover, employment, profits, and industry and country trends, they find that emission reductions were 3.6 percent higher between 2007 and 2008 than between 2005 and 2006. The difference between the two periods is statistically significant and robust to the presence of outliers. The authors argue that the reduction in emissions is due to the change in stringency from phase I to phase II (i.e., the lower allocation of EUAs) and not to a decrease in production. Moreover, they find that firms whose net allocation of EUAs was below the median (i.e., firms that were short of EUAs in 2005) abated the most between 2007 and 2008.

\section{Fuel-switching effects}

In order to estimate the impact of the EU ETS on fuel switching in the UK power sector, McGuinness and Ellerman (2008) use detailed data on power-plant utilization, aggregate demand, and fuel and $\mathrm{CO}_{2}$ costs for coal- and gas-fired combined-cycle gas turbine plants during phase I. They estimate that the EU ETS resulted in abatement in the UK power sector of 13 to 21 million tons of $\mathrm{CO}_{2}$ in 2005 and 2006.

\section{Findings of Qualitative Studies}

The third strand of the literature assesses the emissions impact of the EU ETS based on qualitative data from surveys of market participants. Although the results of such surveys cannot always be generalized, they often provide important insights into the underlying mechanisms that may be driving emissions abatement. However, as is common with surveys, it is up to the respondent to draw his or her own conclusions about causality.

Löschel et al (2010) surveyed 120 German firms, of which only 6 percent stated that the key driver of emissions reductions was the explicit goal to abate emissions. However, for almost 90 percent of the firms, emissions reductions were viewed as a cobenefit of investments motivated by other factors, such as general efficiency improvements. Along the same lines, 94 percent of Swedish EU ETS firms surveyed by Sandoff and Schaad (2009) indicated that they would not reduce their production volume in order to achieve internal emissions abatement, thus placing greater weight on efficiency improvements to reduce emissions. Engels (2009) reports that one-

\footnotetext{
${ }^{9}$ Both studies use a refined version of the DD approach in which participating emitters are matched to observationally similar nonparticipants, as in Fowlie, Holland, and Mansur (2012).

${ }^{10}$ To this end, they match 3,608 installations to the AMADEUS database, a commercial data set that provides financial and balance sheet data for most European firms. About 31 percent of these firms are in the electri city and heat generation sector.
} 
third of more than three hundred firms in Germany, the United Kingdom, Denmark, and the Netherlands surveyed between 2006 and 2008 stated that they did not know their own abatement costs.

Other studies present case-based evidence. According to managers of five industrial companies in Poland and Belgium interviewed by Ikkatai, Ishikawa, and Sasaki (2008) and Ikkatai, Hori, and Kurita (2011), the emission reductions that occurred during the EU ETS were due to economic conditions, not the existence of the EU ETS. Moreover, the perceived incentive for abatement was low at these firms because they benefited from an over-allocation of EUAs. Fazekas (2009) interviewed managers of Hungarian installations responsible for 55 percent of the country's emissions and finds that abatement was driven primarily by cost minimization and compliance with the EU ETS.

In another case study, Walker, Bazilian, and Buckley (2009) find that four cement plants in Ireland failed to substitute forest-derived biomass for fossil fuel despite the existence of the EU ETS. The major barriers to adoption appeared to be technical and logistical concerns, as well as a pulpwood supply risk. Finally, Ellerman, Convery, and de Perthuis (2010) present anecdotal evidence of carbon-emission reductions in the power sector and in selected manufacturing industries throughout the EU. However, they do not claim that the EU ETS caused these reductions. Although the findings of these qualitative studies cannot be interpreted as causal evidence of an EU ETS impact, they may be useful inputs to future quantitative analyses.

\section{Impact of the EU ETS on Economic Performance and Competitiveness}

In order to comply with the EU ETS, regulated firms can either undertake costly abatement or buy EUAs, both of which lower their profits. In addition, regulated firms may lose market share to rival firms outside the EU ETS. In the case of power generation, this competitiveness effect is limited by the institutional and technical aspects of European electricity markets. Indeed, these markets are segmented due to the structure of existing transmission networks, which substantially limits import penetration from countries without a carbon price. For industrial emitters competing in international product markets, however, it may not be feasible to pass through the cost of carbon without losing market share. In such cases, the result would be lower levels of production and employment. In the worst case, firms might relocate in order to avoid compliance with the EU ETS policy, thus moving jobs and carbon emissions to unregulated countries. In response to this risk, policymakers have expressed concern that the EU ETS might have a cost in terms of job losses and achieve too little in terms of reducing global carbon emissions. ${ }^{11}$

Thus, a strand of the literature on the EU ETS has focused on the program's possible impacts on indicators of economic performance (broadly defined), such as profits, revenues, output, and employment. The majority of this literature consists of ex ante assessments, which we do not discuss here. Rather we focus on recent ex post evaluations of the EU ETS based on economic performance data from phase I and phase II. Ex post evaluation of economic performance is easier than the task of quantifying the abatement impact of the EU ETS discussed

\footnotetext{
${ }^{11}$ See the EU ETS Handbook published online by the European Commission, http://ec.europa.eu/clima/publi cations/docs/ets handbook en.pdf.
} 
previously because firm-level data on economic performance is relatively easy to obtain for both the pre- and post-2005 periods. Nevertheless, such analyses still face the challenge of establishing that any measured changes in the economic performance of EU ETS firms are due specifically to the policy itself and not to another factor (e.g., energy prices) that affects all regulated firms. This section first discusses ex post studies that have analyzed employment, output, and profits. We then turn to studies examining whether the EU ETS has had any impact on prices or on trade flows. Finally, we review the relevant qualitative evidence gathered via surveys.

\section{Evidence on Employment, Output, and Profits}

A number of studies use balance-sheet data to estimate the impact of the EU ETS on economic outcome variables, specifically employment, output, and profits. For example, Abrell, Ndoye, and Zachmann (2011), discussed earlier, find no statistically significant impact of the EU ETS on a firm's value-added and profit margins. However, for the 2004-2008 period, they find a small (0.9 percent) but statistically significant decrease in employment at EU ETS firms, which appears to be driven by the nonmetallic minerals sector. Dividing the sample into firms with an over-allocation of EUAs and firms with an under-allocation of EUAs does not yield a clear pattern of heterogeneous responses to the EU ETS, suggesting that the stringency of the allocation does not impact the size of this small effect on employment. However, the authors warn that their approach of using control firms only from nonregulated sectors could mean that the estimated impacts of the EU ETS are confounded by sectoral trends.

In another study, Commins et al. (2011) study the impact of energy taxes and the EU ETS for a panel of 162,771 European firms between 1996 and 2007. They find that the EU ETS has a significant negative effect on return-on-capital, but that the impacts on employment, total factor productivity, and investment are not statistically significant. A limitation of this study is that the treatment variable is defined at the sector level, which means that there is likely a measurement error concerning treatment status and that sector shocks may confound the estimated EU ETS effects.

Chan, Li, and Zhang (2013) analyze a sample of firms in the power, cement, and iron and steel industries in ten countries between 2001 and 2009. ${ }^{12}$ They find statistically significant impacts of the EU ETS only in the power sector, where unit material costs increased by 5 percent in phase I and 8 percent in phase II and turnover increased by 30 percent in phase II.

An early study by Anger and Oberndorfer (2008) answers a slightly different question: How did variation in the allocation of free EUAs during phase I affect firms' employment and revenue? Specifically, for a sample of 419 German EU ETS firms, the authors used the ratio of free EUAs to verified emissions as an indicator of whether a firm's EUA allocation was binding or not. They find that this ratio had no significant impact on changes in firm revenue or employment between 2004 and 2005, although they cannot rule out that these outcomes were simultaneously determined with verified emissions in 2005 , which would mean that they are not measuring the causal impact of the EU ETS.

In addition to using balance-sheet data, researchers have used data from other sources to evaluate the effects of the EU ETS on economic performance and competitiveness. For example, the administrative data sets mentioned in the previous section (e.g., in the French and German

${ }^{12}$ They use a DD approach. 
firm-level studies) provide data on a number of relevant outcome variables such as employment. Using confidential data from Germany, Petrick and Wagner (2014) find no significant impact of the EU ETS on employment at regulated firms. ${ }^{13}$ In contrast, they find small but statistically significant increases in both turnover and exports during the first half of phase II (the last year included is 2010). Although these results hint at the possibility that German firms were able to pass EUA prices on to product prices, the results are not statistically significant in all of the robustness checks. Using French plant-level data, Wagner et al. (2013) find a statistically significant decrease (8 percent) of plant-level employment during phase II (the last year included is 2010) but no significant impact on exports.

These studies have focused explicitly on the manufacturing sector, where carbon pricing may have stronger competitiveness impacts. However, it is both interesting and important to examine the power sector because of its large share of overall EU emissions (i.e., 29.2 percent in 2012). Yu (2011) estimates the impact of the EU ETS on profit margins of electricity and district heating firms in Sweden for the first 2 years of the EU ETS and finds a significant negative effect in 2006. As discussed earlier, one drawback of this type of approach is that firms in the control group might be rather different from the treated (i.e., regulated) group.

Because a firm's stock price reflects its future discounted stream of profits, economists frequently rely on stock-market data to estimate the profit impact of a policy or other events. For example, Veith, Werner, and Zimmermann (2009) estimate the effect of both spot and future carbon prices on daily stock-market returns for the major European power companies during phase I trading. They find that returns on common stock are positively correlated with EUA prices, indicating that power companies profited from freely allocated EUAs and were able to pass through a large enough share of their price to their consumers, thus benefiting from the EU ETS during phase I.

Bushnell, Chong, and Mansur (2013) provide additional empirical evidence on this issue in a study of the impact of carbon pricing on the profits of a sample of 548 firms, all of which are large power generators. ${ }^{14}$ They find that in response to the precipitous fall of the EUA price in April 2006, stock prices dropped for firms in both carbon- and electricity-intensive industries, particularly for firms selling primarily within the EU. Bushnell, Chong, and Mansur (2013) argue that these results suggest that investors focused on the positive impact of emissions trading on product prices (as firms passed through the opportunity costs of EUAs obtained for free), rather than just the negative compliance costs. They also find that a firm's net EUA position influenced how strongly its share price responded to EUA prices. The results of the Bushnell, Chong, and Mansur (2013) study are consistent with the earlier findings of Veith, Werner, and Zimmermann (2009). However, because both studies use relatively small samples and focus only on publicly traded firms, further research is needed to determine whether these results can be generalized to the EU ETS overall.

\section{Evidence on the Pass-Through of Emission Costs}

The studies just discussed suggest that power companies pass through the cost of EUAs to electricity prices. This indicates another-indirect—channel through which the EU ETS affects

\footnotetext{
${ }^{13}$ In addition to nearest neighbor matching, they also employ a DD approach with reweighting.

${ }^{14}$ They use an event study framework.
} 
the industrial sector. More specifically, this suggests that manufacturing firms that compete on international product markets with firms from unregulated countries may be more severely impacted by cap-and-trade than the power sector, where such competition is limited by institutional and technical factors. Thus, a firm's ability to pass through cost increases - from both EUA trading and higher electricity costs - to the product market is widely regarded as an indicator of the competitiveness impacts of the EU ETS.

Research on the pass-through of emission costs in the electricity sector also relates to the controversial issue of "windfall profits" (Ellerman, Marcantonini, and Zaklan 2016), which occur only if the EUA price is passed on to the electricity price. In a widely cited study, Sijm, Neuhoff, and Chen (2006) combine price data on forward and spot market prices of electricity in Germany and the Netherlands with EUA price data to estimate the pass-through of $\mathrm{CO}_{2}$ costs to electricity prices. They find pass-through rates of 60 percent to 100 percent, indicating a substantial scope for windfall profits. Zachmann and von Hirschhausen (2008) analyze weekly electricity prices in Germany during the first 2 years of the EU ETS and find evidence that electricity producers passed on shocks in carbon prices to electricity prices. Moreover, they find that the adjustment (i.e., the change in electricity prices) was larger for positive shocks than for negative shocks (i.e., indicating an asymmetric pass-through).

In a recent study, Fabra and Reguant (2014) use plant-level data on Spanish electricity generators during phase I trading to examine the pass-through of emission costs. The starting point of their analysis is the important insight that incomplete pass-through of the carbon price may be due to various factors, including market power, demand elasticity, or firms not internalizing emission costs in their operating decisions. They find that the pass-through rate of emission costs to electricity prices is 80 percent. They also decompose the different channels that may cause an incomplete pass-through and find that firms internalize the full costs of EUAs. This suggests that increasing the auctioning of EUAs should not increase electricity prices in the short run.

Kirat and Ahamada (2011) analyze the pass-through of the EUA price to day-ahead contract prices observed in the French and German electricity markets during phase I of the EU ETS. Their results indicate that the EUA price explains a significant part of the variation in electricity prices during the first 2 years of phase I. Ahamada and Kirat (2012) show that this elasticity increased during phase II, suggesting that the pass-through rate increased during that time.

To examine pass-through in the manufacturing sector, de Bruyn et al. (2010) estimate the stochastic relationship between industry-specific price indices in the EU versus the United States and the carbon price. Using monthly price data from 2001 to 2009, they find that energy-intensive industries such as iron and steel and oil refining passed through a large fraction of the EUA price to their respective product markets. In a similar analysis, Alexeeva-Talebi (2011) finds that European refineries fully passed through the price of EUAs to retail gasoline prices between 2005 and 2007. Oberndorfer, Alexeeva-Talebi, and Löschel (2010) use the same method to study cost pass-through in several UK industries and find EUA pass-through rates to weekly gasoline and diesel prices of 50 percent to 75 percent for 2005 and 2006. They also present evidence of cost pass-through for glass and ceramics products in the United Kingdom and for chemical products in the EU. Most studies on cost pass-through in the manufacturing sector have been based on time-series variation in fairly aggregate price series. Further research at the firm level would be helpful to increase our understanding of exactly how the EU ETS affects pricing in these often imperfectly competitive markets. 


\section{Evidence from Trade Data}

A more direct test of the competitiveness impacts of the EU ETS can be conducted using trade data. With this in mind, Constantini and Mazzanti (2012) estimate the impact of phase I on net exports from EU15 countries to more than one hundred destination countries and for a broad range of industries. The results indicate that the EU ETS decreased net exports for all industries except medium-low technology industries. One potential drawback of their empirical strategy is that they define the treatment variable (i.e., participation in the EU ETS) at the sector level. Thus, the authors conclude that further disaggregation and longer time series are needed to obtain more reliable impact estimates.

In a study of the aluminum industry, Reinaud (2008) adopts a similar approach, regressing net imports of aluminum into EU27 countries on the year-ahead EUA price and other control variables from 1999 through 2007. Although economic intuition suggests that a higher carbon price will increase net imports of electricity-intensive aluminum from unregulated countries, she finds a negative relationship. However, this negative relationship is not necessarily causal because the analysis does not distinguish between the impact of the EU ETS and a secular, upward trend in net imports. Moreover, Reinaud finds no evidence of a structural break in net imports following the introduction of the EU ETS. Thus, the evidence to date on the impact of the EU ETS on trade is inconclusive.

\section{Evidence from Survey Data}

The competitiveness impacts of the EU ETS have been at the heart of a number of ex ante studies that have relied on both economic modeling and calibration exercises and data collected in surveys. Because some of these surveys were conducted after the start of the EU ETS, we discuss them here as providing relevant ex post evidence of the impact of the EU ETS, although no conclusions should be drawn about causality

Based on interviews with senior managers at six large manufacturing firms in the EU ETS, Kenber, Haugen, and Cobb (2009) find that the EU ETS neither resulted in significant costs nor induced a fundamental shift in strategy (such as relocation or reduction of the workforce). Lacombe (2008) interviewed managers at five European refining companies, who reported only minor economic impacts on their firms. He attributes this result to organizational inertia, weak incentives linked to the low EUA price that prevailed during the second part of phase I, and industrial and regulatory constraints. However, given the small sample size of these studies, the survey results cannot be considered to be representative of the EU ETS overall.

For policymakers, the main concern about competitiveness is not the impact on profits or costs themselves but rather whether such impacts trigger the closure or downsizing of business operations in Europe, resulting in job losses. Martin et al. (2014a, 2014b) examine this issue directly using data collected in 761 interviews with managers of both EU ETS and non-EU ETS firms in six European countries. Managers were asked whether the company planned to downsize operations or relocate abroad in the near future in response to carbon pricing. In addition, EU ETS firms were asked whether this relocation risk depended on the company continuing to receive free EUAs after 2012. Based on the survey responses, the authors construct "vulnerability scores" that capture the subjective risk of downsizing with and without free EUA allocation. They find that the average downsizing risk is low because most firms report that 
future carbon pricing has no impact on their location decisions. However, the downsizing risk score is significantly higher for the average EU ETS firm relative to other firms, although it does not exceed a 10 percent reduction in production or employment. Because of a substantial variation among EU ETS firms in both the level of downsizing risk and the degree to which such risk could be mitigated by providing firms with free EUAs, the authors suggest that the distribution scheme for EUAs should take into account such disparities in relocation risk.

\section{Impact of the EU ETS on Innovation}

The impact of the EU ETS on innovation is of interest to policymakers and researchers to the extent that the development of low-carbon technologies will make it cheaper to reduce carbon emissions. Importantly, if such innovations spill over to other firms, they will help reduce carbon emissions even in sectors or countries where emissions are not regulated. The presence of such spillover effects suggests that even if the EUA price reflects the true social cost of carbon, the level of low-carbon innovation may be inefficiently low because firms are not able to capture the full returns on their research and development (R\&D) investments (Jaffe, Newell, and Stavins 2005). In the context of the EU ETS, we distinguish between direct impacts on innovation by regulated firms and indirect impacts observed for a regulated firm's or industry's technology supplier. It is important to note that an indirect impact requires that a business relationship exist between two firms, whereas a spillover occurs when the firm benefitting from the innovation does not pay for it. We first present evidence from research analyzing large samples of data and then turn to case studies on the impact of the EU ETS on innovation.

\section{Evidence from Large Samples}

Calel and Dechezleprêtre (2015) analyze the direct impact of carbon trading in the EU ETS by comparing patent applications for low-carbon technologies across both EU ETS and non-EU ETS firms. The authors match almost all EU ETS firms to a database of firms registered with the European Patent Office (EPO) between 1979 and 2009. As shown in figure 3, EU ETS firms exhibit a larger increase in low-carbon patenting after 2005 compared with non-EU ETS firms, and this increase is particularly pronounced from the onset of phase II (2008) onwards. Controlling for the substantial preexisting differences between the two groups of firms, the authors find that the EU ETS caused a small but statistically significant increase in low-carbon patenting - 8.1 percent—for EU ETS firms (188 patents) compared with a 0.85 percent increase for all low-carbon patents filed at the EPO. The authors investigate but find no evidence supporting the argument that the EU ETS led to the crowding out of patents that were not classified as low carbon.

Although patent counts are a well-established measure of innovation output, they provide little information about innovation inputs (e.g., the financial and human resources that a firm devotes to R\&D), which may be affected by the EU ETS in a more immediate way. To address this issue, Martin, Muûls, and Wagner (2013) investigate the impact of the EU ETS on clean innovation in processes and products. Using responses from manager interviews for both process and product innovations, the authors rank firms on a scale from one to five to capture the firm's relevant innovation input and find no significant differences in scores between 


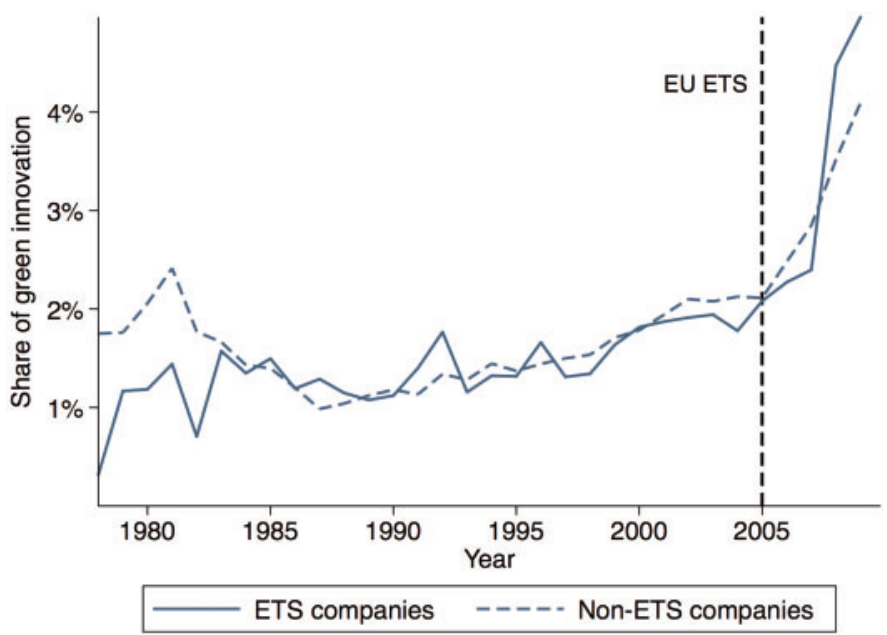

Figure 3 Comparison of low carbon patents (1978-2009)

Source: Calel and Dechezleprêtre (2015).

EU ETS and non-EU ETS firms. ${ }^{15}$ To address the possibility of omitted variables bias, Martin, Muûls, and Wagner (2013) examine whether the innovation score is different for firms below or above the thresholds set by the EU for free allocation of EUAs after 2012. These thresholds imply that firms in very carbon-intensive or trade-exposed sectors will continue to receive free EUAs after 2012. The authors find that firms in sectors just below the thresholds required for free allocation conduct significantly more innovation than those just above those thresholds, suggesting that the EUA allocation mechanism had an effect on firms' innovation decisions.

In another study, Löfgren et al. (2013) analyze technology adoption from 2002 to 2008 for a panel of seven hundred Swedish firms in the energy sector and energy-intensive manufacturing. They compare energy-intensive firms (that are likely to be regulated by the EU ETS) to less energy-intensive firms that are in non-ETS sectors (and thus unlikely to be in the EU ETS unless they have, for example, a very energy-intensive boiler) and find no significant effect of the EU ETS on either large or smaller investments. It is important to note that the period of their analysis covers only the first 8 months of phase II and that the authors do not have specific information on whether firms are actually regulated by the EU ETS.

Borghesi, Cainelli, and Mazzanti (2012) analyze innovation data on one thousand Italian firms and find that a broadly defined measure of environmental innovation is positively correlated with EU ETS participation but negatively correlated with EU ETS stringency (defined at the sector level as emissions divided by EUA allocations). This could suggest that the policy encourages firms to innovate but only in sectors where the allocation of EUAs has not been too stringent.

\section{Evidence from Case Studies}

A number of studies of the impact of the EU ETS on innovation rely on very small data sets, which likens them to case studies. For example, based on interviews with twenty-seven EU ETS

${ }^{15}$ This is in line with a result Martin et al. (2012) obtained in interviews with managers at medium sized manufacturing firms in the United Kingdom. 
firms in Ireland, Anderson, Convery, and Di Maria (2011) conclude that phase I of the EU ETS stimulated a shift toward cleaner technologies and raised awareness about emissions reduction possibilities.

Rogge et al. (2011) conducted interviews with managers at thirty-six companies in the pulp and paper sector in Germany between June 2008 and September 2009.The EU ETS was ranked only seventh among several determinants of $\mathrm{R} \& \mathrm{D}$ activities among paper producers, only 21 percent of which thought it was very relevant. Factors that ranked higher include market forces (e.g., the price of raw materials) and technology-specific regulation. None of the respondents expected near-term changes, but two-thirds of them expected that, by 2020, the relevance of R\&D would rise due to climate policy.

Rogge and Hoffmann (2010), Hoffmann (2007), and Rogge, Schneider, and Hoffmann (2011) report on a number of interviews with managers of (and experts on) electricity-generation industries in Germany. They conclude that the EU ETS (1) had an impact on innovation activities specific to certain generation technologies and (2) was important for accelerating research on efficiency improvements in fossil-fuel technologies as well as for launching research on carbon capture and storage. The EU ETS was found to be less relevant for renewable energy because feed-in tariffs provided stronger incentives than the relatively low EUA prices.

Based on a survey of thirty-eight Italian paper manufacturers in 2006, Pontoglio (2008) reports that most firms (66 percent) were short of EUAs and that 72 percent of them addressed this shortage by borrowing EUAs. He also found that half of the firms had not undertaken efforts to reduce emissions (e.g., through investments in new technologies) and that the other half had undertaken such efforts or were planning to do so. Interviews with equipment suppliers revealed that none of them intended to focus on energy or $\mathrm{CO}_{2}$ efficiency as a selling point for their company or their products. Although these results based on case studies provide interesting insights on specific sectors, econometric studies are needed in order to draw conclusions about the innovation impacts of the EU ETS.

\section{Conclusions and Future Research Needs}

This article has reviewed the small but rapidly growing scholarly literature on the ex post evaluation of the EU ETS. The main challenge encountered by these studies is disentangling the causal impacts of the EU ETS from the effect of confounding factors on the outcomes of interest. In fact, most of the available literature to date has focused on correlation rather than causation. Whereas early studies either used aggregate data or focused on a small number of firms in a particular sector and country, more recent studies have increasingly relied on microdata to establish causal impact estimates on the basis of large and representative samples.

First, concerning the issue of carbon emissions, the available evidence suggests that the EU ETS has had a robust negative impact on them. Sector-level studies find that emissions across all regulated sectors_energy and industry_-declined by around 3 percent in phase I and during the first 2 years of phase II, relative to estimated business-as-usual emissions. Based on firmlevel data for France and Germany, there is robust evidence of a reduction in emissions by industrial firms during phase II (in the range of 10 percent to 26 percent), but not during phase I.

Second, concerning the issue of whether these emissions reductions might have diminished economic performance, the empirical evidence does not support the view that the EU ETS had 
strong detrimental effects, although there is a fair amount of heterogeneity across studies and outcomes. Power companies profited from freely allocated EUAs and otherwise passed through the cost of EUAs at the margin. Regarding manufacturing, the results are mixed, with some studies finding a negative employment impact during phase II, but others finding no significant reduction in turnover and employment and no evidence of an effect on aggregate trade flows. However, in a large-scale survey among manufacturing firms, EU ETS participants report a slightly higher propensity to downsize their operations in response to future carbon pricing than non-ETS firms.

For the EU ETS to be dynamically efficient, it must provide incentives not only for emissions abatement in the short run but also for innovation in clean technologies. This is why the third issue we examined was innovation. Clean innovation has experienced a steep increase since 2005, and there is robust evidence that the EU ETS caused a small part of this increase in phase II. This is in line with survey evidence suggesting that renewable energy obligations and feed-in tariffs in power generation were stronger drivers of innovation than carbon trading.

As a research endeavor, impact analysis of the EU ETS is still very much a work in progress. On the one hand, this reflects the nature of the EU ETS as an ongoing and continuously evolving policy instrument. On the other hand, further research is needed in several areas. First, there are the methodological challenges of identifying causality between the EU ETS and emission reductions, economic performance and competitiveness, and innovation in the industrial and power sectors. Although some of these challenges arise from the policy design itself - particularly the fact that participation of firms in the EU ETS is not random-others are due to a lack of suitable data or other constraints. Thus, one priority for future research on the EU ETS is the further development of firm-level microdata, in terms of both outcome variables and geographical coverage.

When examining the impact of the EU ETS on emissions, rather than using aggregate emissions data, administrative microdata facilitates the application of econometric techniques aimed at establishing causality_-for example, by controlling for aggregate shocks, differences in the characteristics of treated and untreated firms, differential pretrends, and other confounding factors. Applying such techniques to microdata from a large set of countries will improve our understanding of the impacts of the EU ETS on abatement.

The same can be said about the competitiveness impacts of the EU ETS. Although firm-level performance indicators have been easier to obtain than emissions data, current research has far from exhausted the full range of relevant outcome variables. In particular, there is a lack of firmlevel studies on the pass-through of compliance cost and on the impact of the EU ETS on the exporting behavior of industrial emitters. Likewise, little is known thus far about the impacts of the EU ETS on market structure or on the size distribution of firms.

The evaluation of the innovation impact of the EU ETS should pay more attention to clean innovation by technology providers of regulated industries. Another issue worth studying is whether clean innovation crowds out dirty innovation, as this might have repercussions for macroeconomic growth. For example, innovation effects entail the possibility of "green growth" in the EU if clean innovation spills over more easily among regulated economies than the innovation it has replaced. Not least, the magnitude and direction of spillovers of clean innovation should be the subject of a thorough investigation because such spillovers have the potential to reduce carbon emissions even in currently unregulated countries like China and 
India. This kind of clean innovation impact of the EU ETS would allow Europe to "punch above its carbon weight."

Finally, more research is needed on the underlying mechanisms behind a firm's response to the carbon price and to institutional details surrounding EUA allocation. It would be interesting to examine whether firms are indeed acting as rational market participants, taking account of the carbon price at all levels of management. If instead firms view emissions trading as just another command-and-control instrument, they will simply pay for missing EUAs at the end of each reporting period. Although there is some preliminary evidence from representative surveys (Martin, Muûls, and Wagner 2015), detailed firm-level information on trading patterns is also becoming available through the EUTL transaction database and may shed some light on this issue.

For academics, closing these research gaps is a goal in its own right. However, increasing our understanding of the impact of the EU ETS also has important real-world implications for both improving the design of emissions trading schemes worldwide and informing the ongoing global climate policy debate.

\section{References}

Abrell, J., A. Ndoye, and G. Zachmann. 2011. Assessing the impact of the EU ETS using firm level data. Bruegel Working Paper 2011/08, Brussels, Belgium.

Ahamada, I., and D. Kirat. 2012. The impact of phase II of the EU ETS on the electricity generation sector. Documents de travail du Centre

d'Economie de la Sorbonne 12007, Université Panthéon Sorbonne, Paris.

Alexeeva Talebi, V. 2011. Cost pass through of the EU emissions allowances: Examining the European petroleum markets. Energy Economics 33 (S1): S75 S83.

Anderson, B., F. Convery, and C. Di Maria. 2011. Technological change and the EU ETS: The case of Ireland. IEFE Working Paper No. 43, Bocconi University, Milan, Italy.

Anderson, B., and C. Di Maria. 2011. Abatement and allocation in the pilot phase of the EU ETS. Environmental and Resource Economics 48: 83103.

Anger, N., and U. Oberndorfer. 2008. Firm per formance and employment in the EU Emissions Trading Scheme: An empirical assessment for Germany. Energy Policy 36 (1): 1222.

Borghesi, S., G. Cainelli, and M. Mazzanti. 2012. Brown sunsets and green dawns in the industrial sector: Environmental innovations, firm behavior and the European emission trading. FEEM Working Paper No. 3.2012, Milan, Italy.
Bundeswirtschaftsministerium der Bundesrepublik Deutschland (BBD). 2008. Energiedatensammlung vom 2.1.2008. Retrieved from http://www.bmwi. de/BMWi.

Bushnell, J. B., H. Chong, and E. T. Mansur. 2013. Profiting from regulation: Evidence from the European Carbon Market. American Economic Journal: Economic Policy 5 (4): 78106.

Calel, R., and A. Dechezleprêtre. 2015.

Environmental policy and directed technological change: Evidence from the European carbon market. Review of Economics and Statistics 10.1162/ REST a 00470.

Chan, H. S., S. Li, and F. Zhang. 2013. Firm com petitiveness and the European Union emissions trading scheme. Energy Policy 63: 105664.

Commins, N., S. Lyons, M. Schiffbauer, and N. C. Tol. 2011. Climate policy and corporate behavior. Energy Journal 32 (4): 5168.

Cooper, R. 2010. Europe's Emissions Trading System. Harvard Project on International Climate Agreements Discussion Paper, Cambridge, MA. Constantini, V., and M. Mazzanti. 2012. On the green and innovative side of trade competitiveness? The impact of environmental policies and innov ation on EU exports. Research Policy 41 (1): 13253. de Bruyn, S., A. Markowska, F. de Jong, and M. Bles. 2010. Does the energy intensive industry obtain windfall profits through the EU ETS? An 
econometric analysis for products from the refi neries, iron and steel and chemical sectors. CE Delft Publication No. 10.7005.36, Delft, the Netherlands.

Delarue, E., K. Voorspools, and W. D'haeseleer. 2008. Fuel switching in the electricity sector under the EU ETS: Review and prospective. Journal of Energy Engineering 134: 4046.

Delarue, E. D., A. D. Ellerman, and W. D. D'haeseleer. 2010. Short term $\mathrm{CO}_{2}$ abatement in the European power sector: 2005 2006. Climate Change Economics 1 (2): 11333.

Department for Energy and Climate Change (DECC). 2013. 2013 UK greenhouse gas emissions: final figures data tables.

Deutsche Emissionshandelsstelle (DEHSt). 2005. Implementation of emissions trading in the $\mathrm{EU}$ : National Allocation Plans of all EU States. Prepared in cooperation with the Fraunhofer Institute for Systems and Innovation Research and the Öko Institut. Berlin.

Egenhofer, C., M. Alessi, N. Fujiwara, and A. Georgiev. 2011. The EU Emissions Trading System and climate policy towards 2050: Real incentives to reduce emissions and drive innovation? CEPS Special Report, Centre for European Policy Studies.

Ellerman, A. D., and B. K. Buchner. 2007. The European Union Emissions Trading Scheme: Origins, allocation, and early results. Review of Environmental Economics and Policy 1 (1): 6687.

. (2008). Over allocation or abatement? A preliminary analysis of the EU ETS based on the 2005/06 emissions data. Environmental and Resource Economics 41 (2): 26787.

Ellerman, A. D., F. J. Convery, and C. de Perthuis. 2010. Pricing carbon: The European Union Emissions Trading Scheme. Cambridge, UK: Cambridge University Press.

Ellerman, A. D., and S. M. Feilhauer. 2008. A top down and bottom up look at emissions abatement in Germany in response to the EU ETS. Working Paper 2008 017, MIT Center for Energy and Environmental Policy Research, Cambridge, MA. Ellerman, A. D., C. Marcantonini, and A. Zaklan. 2016. The European Union Emissions Trading System: Ten years and counting. Review of Environmental Economics and Policy 10 (1): 89107.
Engels, A. 2009. The European Emissions Trading Scheme: An exploratory study of how companies learn to account for carbon. Accounting, Organizations and Society 34 (3 4): 48898. European Environmental Agency (EEA). 2007. Annual European Community greenhouse gas inventory 19902005 and inventory report 2007. EEA Technical Report No 7/2007 Copenhagen.

Fabra, N., and M. Reguant. 2014. Pass through of emissions costs in electricity markets. American Economic Review 104 (9): 287299.

Fazekas, D. 2009. Carbon market implications for new EU member states: Empirical analysis for Hungary. PhD diss., Corvinus University.

Fowlie, M., S. P. Holland, and E. Mansur. 2012. What do emissions markets deliver and to whom? Evidence from Southern California's NOx trading program. American Economic Review 102 (2): 96593.

Greenstone, M., and T. Gayer. 2009. Quasi experi mental and experimental approaches to environ mental economics. Journal of Environmental Economics and Management 57 (1): 2144.

Herold, A. 2007. Comparison of verified $\mathrm{CO}_{2}$ emis sions under the EU Emission Trading Scheme with national greenhouse gas inventories for the year 2005. ETC/ACC Technical Paper no. 2007/3, European Topic Center on Air and Climate Change, Bilthoven.

Hintermann, B., S. Peterson, and W. Rickels. 2016. Price and market behavior in phase II of the EU ETS: A review of the literature. Review of Environmental Economics and Policy 10 (1): 10828.

Hoffmann, V. H. 2007. EU ETS and investment decisions: The case of the German electricity indus try. European Management Journal 25 (6): 46474. Ikkatai, S., K. Hori, and I. Kurita. 2011. The impact of the European Union Emissions Trading Scheme on the Polish economy: Interviews with four companies in Poland. KIER Discussion Paper. http://www.kier.kyoto u.ac.jp/DP/DP786.pdf.

Ikkatai, S., D. Ishikawa, and K. Sasaki. 2008. Effect of the European Union Emission Trading Scheme (EU ETS) on companies: Interviews with European companies. KIER Working Papers 660, Kyoto University, Institute of Economic Research. Jaffe, A. B., R. G. Newell, and R. N. Stavins. 2005. A tale of two market failures: Technology and 
environmental policy. Ecological Economics 54 (2 3): 16474 .

Kenber, M., O. Haugen, and M. Cobb. 2009. The effects of EU climate legislation on business competitiveness: A survey and analysis.

Washington, DC: German Marshall Fund of the United States.

Kettner, C., D. Kletzan Slamanig, and A. Koppl. 2011. The EU Emission Trading Scheme Allocation patterns and the effects of the economic crisis. WIFO Working Papers 408/2011, Vienna, Austria.

Kirat, D., and I. Ahamada. 2011. The impact of the European Union Emissions Trading Scheme on the electricity generation sector. Energy Economics 33 (5): 9951003.

Lacombe, R. H. 2008. Economic impact of the European Union Emission Trading Scheme: Evidence from the refining sector. Master's thesis, Massachusetts Institute of Technology.

Lofgren, A., M. Wråke, T. Hagberg, and S. Roth. 2013. The Effect of EU ETS on Swedish industry's investment in carbon mitigating technologies. Working Papers in Economics 565, Department of Economics, University of Gothenburg.

Loschel, A., P. Heindl, V. Alexeeva Talebi, V. Lo, and A. Detken. 2010. KfW/ZEW $\mathrm{CO}_{2}$ panel: Vermeiden oder kaufen Deutsche Unternehmen im Emissionshandel. Zeitschrift fur Energiewirtschaft 34 (1): 3946.

Martin, R., M. Muûls, L. B. De Preux, and U. J. Wagner. 2012. Anatomy of a paradox:

Management practices, organizational structure and energy efficiency. Journal of Environmental Economics and Management 63 (2): 20823.

. (2014a). Industry compensation under re location risk: A firm level analysis of the EU Emissions Trading Scheme. American Economic Review 104 (8): 2482508.

. (2014b). On the empirical content of carbon leakage criteria in the EU Emissions Trading Scheme. Ecological Economics 105: 7888.

Martin, R., M. Muûls, and U. J. Wagner. 2012. An evidence review of the EU Emissions Trading System, focussing on effectiveness of the system in driving in dustrial abatement. Report for the UK Department for Energy and Climate Change.

. (2013). Carbon markets, carbon prices and innovation: Evidence from interviews with managers. Paper presented at the Annual Meetings of the American Economic Association, San Diego.

. (2015). Trading Behavior in the EU Emissions Trading Scheme. In Emissions trading as a policy instrument: Evaluation and prospects, ed. M. Gronwald and B. Hintermann, 213 38, Cambridge, MA, USA: MIT Press.

McGuinness, M., and A. D. Ellerman. 2008. $\mathrm{CO}_{2}$ abatement in the UK power sector: Evidence from the EU ETS trial period. Center for Energy and Environmental Policy Research Working Paper no. 0810, Massachusetts Institute of Technology.

Oberndorfer, U., V. Alexeeva Talebi, and A. Loschel. 2010. Understanding the competitiveness implications of future phases of EU ETS on the in dustrial sectors. Discussion Paper No. 10 044, ZEW Centre for European Economic Research, Mannheim, Germany.

Petrick, S., K. Rehdanz, and U. J. Wagner. 2011. Energy use patterns in German industry: Evidence from plant level data. Journal of Economics and Statistics 231 (3): 379414.

Petrick, S., and U. J. Wagner. 2014. The impact of carbon trading on industry: Evidence from German manufacturing firms. Kiel Working Paper No. 1912, Kiel, Germany.

Pontoglio, S. 2008. The role of environmental policies in the eco innovation process: Evidences from the European Union Emission Trading Scheme. Paper presented at DIME International Conference Innovation, Sustainability and Policy, GREThA, University Montesquieu Bordeaux IV, France.

Reinaud, J. 2008. Climate policy and carbon leak age: Impacts of the European emissions trading scheme on aluminium. IEA Information Paper. OECD/IEA, Paris, France.

Rogge, K. S., and V. H. Hoffmann. 2010. The impact of the EU ETS on the sectoral innovation system for power generation technologies Findings for Germany. Energy Policy 38 (12): 763952.

Rogge, K. S., J. Schleich, P. Haussmann, A. Roser, and F. Reitze. 2011. The role of the regulatory framework for innovation activities: the EU ETS and the German paper industry. International Journal of Technology, Policy and Management 11 (3): 25073. 
Rogge, K. S., M. Schneider, and V. H. Hoffmann. 2011. The innovation impact of the EU Emission Trading System Findings of company case studies in the German power sector. Ecological Economics 70 (3): 51323.

Sandoff, A., and G. Schaad. 2009. Does EU ETS lead to emission reductions through trade? The case of the Swedish emissions trading sector par ticipants. Energy Policy 37 (10): 396777.

Sijm, J., K. Neuhoff, and Y. Chen. 2006. $\mathrm{CO}_{2}$ cost pass through and windfall profits in the power sector. Climate Policy 6 (1): 4972.

Trotignon, R., and A. Delbosc. 2008. Allowance trading patterns during the EU ETS trial period: What does the CITL reveal? CDC Climat Climate Reports No. 13.

Veith, S., J. R. Werner, and J. Zimmermann. 2009. Capital market response to emission rights returns: Evidence from the European power sector. Energy Economics 31 (4): 60513.
Wagner, U. J., M. Muûls, R. Martin, and J. Colmer. 2013. An evaluation of the impact of the EU emissions trading system on the indus trial sector. Plant level evidence from France. Paper presented at the AERE Conference, Banff, Canada.

Walker, N., M. Bazilian, and P. Buckley. 2009. Possibilities of reducing $\mathrm{CO}_{2}$ emissions from energy intensive industries by the increased use of forest derived fuels in Ireland. Biomass and Bioenergy 33 (9): 122938.

Yu, H. 2011. The EUETS and firm profits: An ex post analysis for Swedish energy firms. Working Paper, Department of Economics, Uppsala University.

Zachmann, G., and C. von Hirschhausen. 2008. First evidence of asymmetric cost pass through of EU emissions allowances: Examining whole sale electricity prices in Germany. Economics Letters 99 (3): 46569. 